\title{
An assessment of the reproducibility and safety of 2-deoxy-D-glucose as a gastric acid stimulant in duodenal ulcer patients
}

\author{
A. L. GOUGH AND N. C. KEDDIE
}

From the Manchester Royal Infirmary

SUMMARY In studying the effects of 2-deoxy-D-glucose (2-DG) on the vagus nerve in preoperative patients with duodenal ulcer we have concluded that (1) in initiating gastric acid secretion 2-DG produces a response that is reproducible after 30 days; (2) 2-DG when given in a dose of $40 \mathrm{mg} / \mathrm{kg}$ intravenously produces a glucopenic state that appears safe in an otherwise healthy patient.

We consider that 2-DG is a worthwhile agent in the investigation of the duodenal ulcer patient.

2-Deoxy-D-glucose (2-DG) has been used for several years as a vagal stimulant to induce gastric acid secretion both in animals (Hirschowitz and Sachs, 1965; Eisenberg, Emås, and Grossman, 1966) and in man (Duke, Hirschowitz, and Sachs, 1965). Among the aspects of its activity as yet unreported is the reproducibility of response in the individual patient. This study investigates this problem and employs gastric function tests in duodenal ulcer patients. Duplicate tests carried out on each patient with an interval of $\mathbf{3 0}$ days were compared with respect to peak acid output and two-hour total acid output. The nature of any side effects occurring during the tests was also evaluated in the light of reports of patients developing atrial fibrillation (Duke et al, 1965), jaundice and hypothermia (Thomas and Duthie, 1968), and the theoretical possibility of irreversible hypoglycaemia (Himsworth and Colin-Jones, 1969).

\section{Method}

Twenty-five patients (23 males and two females, mean age 28.7 years), all with symptomatic and radiologically proven duodenal ulceration, took part in the study after their informed consent had been obtained. All were otherwise healthy and they were carefully screened for cardiovascular or hepatic disease and diabetes before admission to the study.

After an overnight fast a no. 14 FG nasogastric tube was positioned in the stomach. A satisfactory water recovery test (Hassan and Hobsley, 1970; Received for publication 7 January 1975.
Findlay, Prescott, and Sircus, 1972) provided evidence of correct placing. Continuous suction at 10 to $30 \mathrm{~mm} \mathrm{Hg}$ was augmented by intermittent manual aspiration. The fasting juice was removed and two 15-minute basal collections were taken. 2-Deoxy-D-glucose in a dose of $40 \mathrm{mg} / \mathrm{kg}$ was given rapidly intravenously as a $20 \%$ solution. A further eight 15-minute samples were then taken to complete the test. The gastric juice samples were titrated with $0.1 \mathrm{~N} \mathrm{NaOH}$ to an endpoint at $\mathrm{pH} 7 \cdot 0$. The results were analysed using the $t$ test for paired values.

Estimations of plasma glucose (using the glucose oxidase method), serum electrolytes, serum glutamyl oxalic transaminase (SGOT), and serum glutamyl pyruvic transaminase (SGPT) were made on venous samples immediately preceding the test and at one and two hours after the administration of 2-DG. All patients were under continual observation for the development of side effects and a record of pulse rate, blood pressure, respiratory rate, and temperature was made at 15-minute intervals throughout each test. An electrocardiograph was taken before and two hours after 2-DG had been given. At the completion of the test the patients were given a meal and all were able to go home within two hours. A second identical test was carried out one month later, after which the ulcer was treated surgically.

\section{Results}

All the subjects tested showed a prompt and sustained response to 2-DG (fig 1). There was significant correlation during all periods of the tests (table I). 


\begin{tabular}{|c|c|c|c|c|c|c|c|c|}
\hline & \multicolumn{8}{|c|}{ Fifteen-minute Collection Period } \\
\hline & 1 & 2 & 3 & 4 & 5 & 6 & 7 & 8 \\
\hline $\begin{array}{l}\text { First Test } \\
\text { Mean } \pm \text { SE (m-equiv) } \\
\text { Second Test }\end{array}$ & $\begin{array}{r}3.86 \\
\pm 0.51\end{array}$ & $\begin{array}{r}8.24 \\
\pm 1.04\end{array}$ & $\begin{array}{r}10.17 \\
\pm 1.01\end{array}$ & $\begin{array}{r}10.80 \\
\pm 0.82\end{array}$ & $\begin{array}{r}9.40 \\
\pm 0.65\end{array}$ & $\begin{array}{r}9 \cdot 14 \\
\pm 1.00\end{array}$ & $\begin{array}{r}\mathbf{7 . 6 8} \\
+\mathbf{0 . 9 2}\end{array}$ & $\begin{array}{r}5.90 \\
\pm 0.60\end{array}$ \\
\hline Mean \pm SE (m-equiv) & $\begin{array}{r}4.39 \\
\pm 0.61\end{array}$ & $\begin{array}{r}8.08 \\
\pm 1.01\end{array}$ & $\begin{array}{r}9.43 \\
\pm 1.28\end{array}$ & $\begin{array}{r}11.86 \\
\pm 1.23\end{array}$ & $\begin{array}{r}9.19 \\
+1.20\end{array}$ & $\begin{array}{r}9.71 \\
\pm 1.28\end{array}$ & $\begin{array}{r}8.70 \\
\pm 1.05\end{array}$ & $\begin{array}{r}7.34 \\
\pm 0.84\end{array}$ \\
\hline Correlation & $\begin{array}{l}r=0.5103 \\
P<0.01\end{array}$ & $\begin{array}{l}r=0.5785 \\
P<0.01\end{array}$ & $\begin{array}{l}r=0.5730 \\
P<0.01\end{array}$ & $\begin{array}{l}r=0.6030 \\
P<0.001\end{array}$ & $\begin{array}{l}r=0.4990 \\
P<0.01\end{array}$ & $\begin{array}{l}r=0.4590 \\
P<0.02\end{array}$ & $\begin{array}{l}r=0.3620 \\
P<0.1\end{array}$ & $\begin{array}{l}r=0.330 \\
P<0.1\end{array}$ \\
\hline
\end{tabular}

Table I Mean $\pm S D$ of each 15-minute collection of gastric juice showing the correlation coefficient and its significance between tests 1 and 2

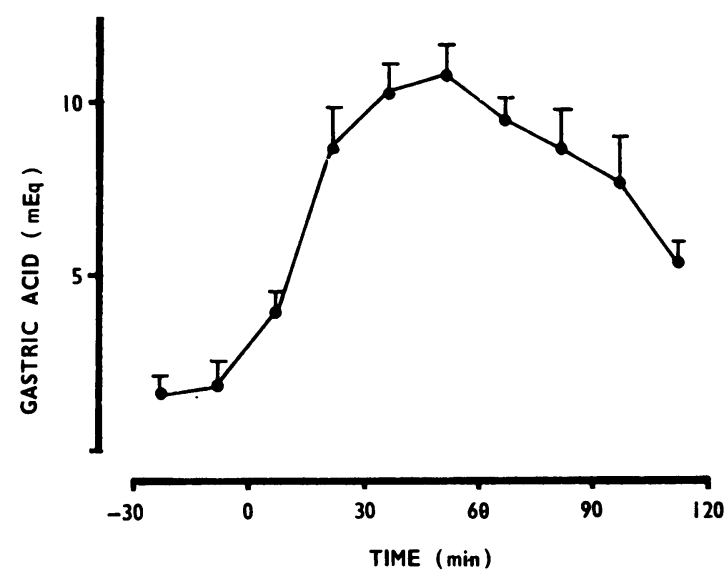

Fig 1 Fifteen-minute outputs of gastric acid, showing the mean plus standard error positions from the total of 50 tests. 2-DG was given at time $O$.

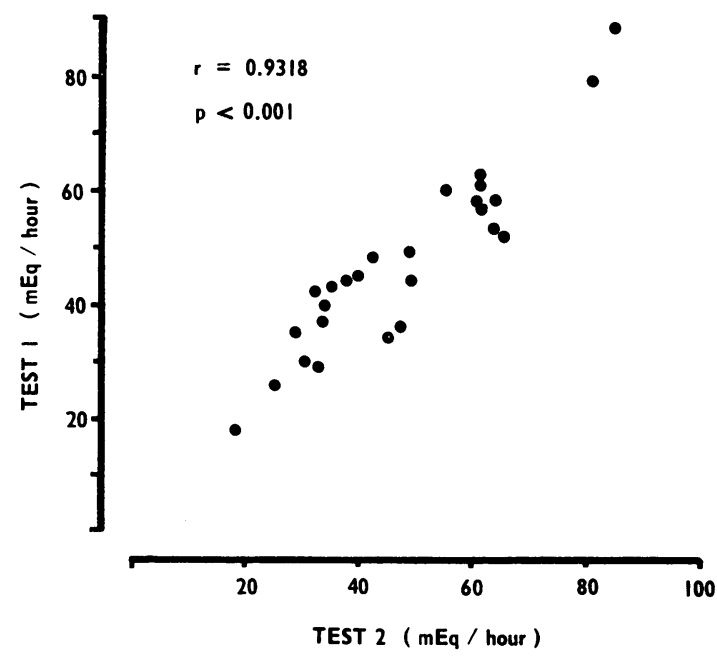

Fig 2 Correlation between peak acid outputs of the first and second series of tests.

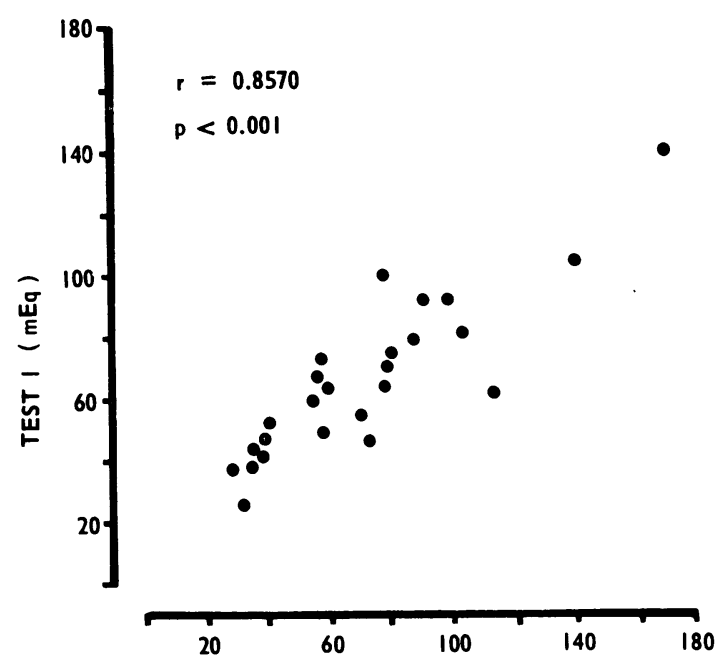

Fig 3 Correlation between two-hour total acid outputs of the first and second series of tests.

The paired results for acid secretion showed several noteworthy features: (a) The values for peak acid output (PAO) had a highly significant correlation between the tests $(P<0.001)$ (fig 2) (the PAO is obtained by doubling the peak 30 -minute output). (b) The time at which the PAO occurred varied by no more than 15 minutes in any of the pairs of tests $(P<0.001)$. (c) The two-hour total acid output following administration of 2-DG showed a highly significant correlation between paired tests $(\mathrm{P}<$ 0.001) (fig 3). (d) The peak acid concentration (PAC) varied slightly in each pair of tests, but the relationship in the group reached a significant level $(P<$ 0.01) (fig 4). However, the time at which the PAC was reached was not constant $(\mathrm{P}>0.05)$. (e) The paired values for fasting concentration showed individual variation but as a group exhibited good correlation $(P<0.01)$. The variations were unassociated with a change in the patients' symptoms. (f) The basal hour measurements showed wide in- 


\begin{tabular}{|c|c|c|c|c|c|c|c|c|c|}
\hline \multirow[t]{2}{*}{ Measurement } & \multicolumn{9}{|c|}{ Time Interval in Minates } \\
\hline & 0 & 15 & 30 & 45 & 60 & 75 & 90 & 105 & 120 \\
\hline $\begin{array}{l}\text { Diastolic blood pressure } \\
\pm \mathrm{SD}(\mathrm{mm} \mathbf{H g})\end{array}$ & $\begin{array}{r}77.7 \\
\pm 8.9 \\
P\end{array}$ & $\begin{array}{c}73.1 \\
\pm 8.73 \\
>0.05\end{array}$ & $\begin{array}{c}68.3 \\
+10.4 \\
<0.005\end{array}$ & $\begin{array}{l}\quad 66.9 \\
+9.9 \\
<0.001\end{array}$ & $\begin{array}{l}67.5 \\
+10.0 \\
<0.001\end{array}$ & $\begin{array}{c}67.7 \\
+10.4 \\
<0.005\end{array}$ & $\begin{array}{r}\quad 67.5 \\
\pm 10.6 \\
<0.005\end{array}$ & $\begin{aligned} & 68.8 \\
\pm & 9.5 \\
< & 0.005\end{aligned}$ & $\begin{array}{r}70.2 \\
\pm \quad 8.4 \\
<0.01\end{array}$ \\
\hline Pulse rate \pm SD (min) & $\begin{array}{r}70.8 \\
\pm 7.2 \\
P\end{array}$ & $\begin{array}{r}73.8 \\
\pm 8.2 \\
>0.2\end{array}$ & $\begin{aligned} & 75.3 \\
\pm & 8.6 \\
< & 0.05\end{aligned}$ & $\begin{array}{r}73.6 \\
\pm 7.8 \\
>0.1\end{array}$ & $\begin{array}{r}72.9 \\
\pm 7.9 \\
>0.3\end{array}$ & $\begin{array}{r}74.0 \\
\pm 8.0 \\
>0.1\end{array}$ & $\begin{array}{r}73.9 \\
\pm 7.9 \\
>0.1\end{array}$ & $\begin{aligned} & 74.1 \\
\pm & 7.2 \\
> & 0.05\end{aligned}$ & $\begin{array}{r}73.8 \\
\pm 7.7 \\
>0.1\end{array}$ \\
\hline Temperature $\pm \mathrm{SD}\left({ }^{\circ} \mathrm{C}\right)$ & $\begin{array}{r}36.92 \\
\pm 0.33 \\
P\end{array}$ & $\begin{aligned} & 36.95 \\
\pm & 0.32 \\
> & 0.3\end{aligned}$ & $\begin{aligned} & 36.83 \\
\pm & 0.41 \\
> & 0.1\end{aligned}$ & $\begin{array}{r}36.90 \\
\pm 0.22 \\
>0.35\end{array}$ & $\begin{array}{r}36.88 \\
\pm 0.28 \\
>0.25\end{array}$ & $\begin{array}{r}36.86 \\
\pm 0.35 \\
>0.15\end{array}$ & $\begin{array}{r}36.90 \\
\pm 0.26 \\
>0.35\end{array}$ & $\begin{array}{r}36.87 \\
\pm 0.42 \\
>0.25\end{array}$ & $\begin{array}{r}36.85 \\
\pm 0.39 \\
>0.15\end{array}$ \\
\hline Respiratory rate $\pm \mathrm{SD}$ (min) & $\begin{array}{r}21.36 \\
\pm 2.55 \\
P\end{array}$ & $\begin{array}{r}21.00 \\
\pm 2.89 \\
>0.25\end{array}$ & $\begin{array}{r}21.50 \\
\pm 2.40 \\
>0.35\end{array}$ & $\begin{array}{l}22.03 \\
\pm 3.12 \\
>0.1\end{array}$ & $\begin{array}{r}21.80 \\
\pm 2.48 \\
>0.15\end{array}$ & $\begin{aligned} & 22.08 \\
\pm & 3.10 \\
> & 0.1\end{aligned}$ & $\begin{array}{r}20.80 \\
\pm 2.90 \\
>0.15\end{array}$ & $\begin{aligned} & 20.96 \\
\pm & 3.00 \\
> & 0.2\end{aligned}$ & $\begin{aligned} 20.98 \\
\pm 2.58 \\
>0.2\end{aligned}$ \\
\hline
\end{tabular}

Table II Readings of blood pressure, pulse rate, temperature and respiratory rate taken at 15-minute intervals throughout each test

${ }^{1}$ The levels are the mean $\pm \mathrm{SD}$ of 50 tests and the significant levels compare subsequent readings with the control level at time $\mathrm{O}$ just before the 2-DG was given.

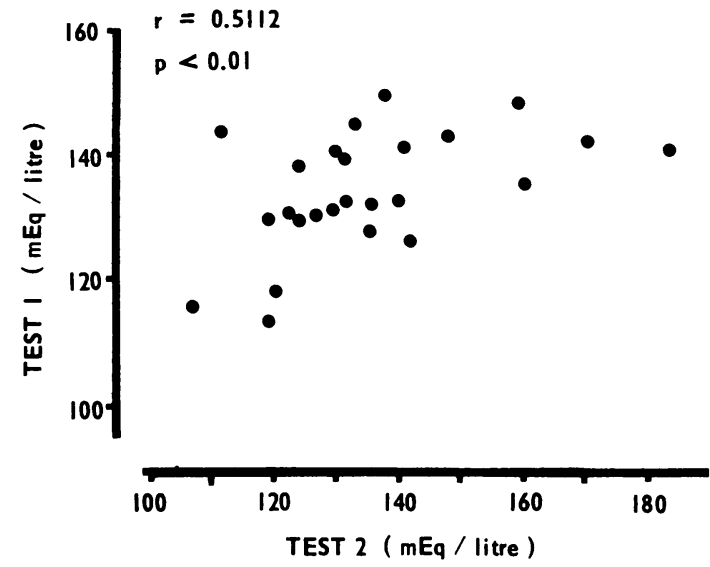

Fig 4 Correlation between the peak acid concentrations of the first and second series of tests.

dividual variation and as a group no close relation was found ( $P>0.05)$.

Table II shows the variation in pulse, blood pressure, respiratory rate, and temperature over the 50 tests. It is evident that no patient exhibited any potentially harmful deviation in these parameters. The fall in the diastolic blood pressure, whilst being highly significant statistically, was not matched by a fall in the systolic levels compared with control readings. There was a rise in pulse rate which reached a significant level at $\mathbf{3 0}$ minutes only. In particular the hypothermic state reported by Thomas and Duthie (1968) was not encountered.

A subjective assessment of the side effects, both by the patient himself and by the person conducting the test (who was the same for every test), is shown in table III. All the effects are those attributable to hypoglycaemia and were in no case severe. Their frequency was rather less than those reported in other series. It is interesting that the symptoms and signs of hypoglycaemia had disappeared by two hours in our patients even though all were still producing significant amounts of acid at this time.

\begin{tabular}{lc}
\hline Side Effect & Number of Patients \\
\hline Sweating & 22 \\
Excessive hunger & 7 \\
Somnolence & 13 \\
Weakness & 4 \\
Headache & 2 \\
Thirst & 1 \\
Nausea & 1 \\
Paraesthesiae & 1 \\
Abdominal cramp & 1
\end{tabular}

Table III Subjective side effects following administration of $2-D G$

The biochemical evaluation is summarized in table IV. The SGOT and SGPT showed no change over the two hours but there was an expected significant fall in serum potassium concentration $(P<$ 0.001 ) at one and two hours compared with basal levels and a similar significant rise in plasma glucose levels $(P<0.001)$.

Table $V$ shows the effect of two hours hypoglycaemia on the electrocardiograph in the $\mathbf{5 0}$ tests. No significant differences were found at two hours compared with the normoglycaemic tracings. 


\begin{tabular}{|c|c|c|c|c|}
\hline & Control & One Hour & Two Hours & $\begin{array}{l}\text { Significance of } \\
\text { One Hour/Two Hours }\end{array}$ \\
\hline $\begin{array}{l}\text { Serum } \mathrm{K}^{+} \\
\text {Mean } \pm \text { SD (m-equiv) }\end{array}$ & $4.33 \pm 0.42$ & $\begin{array}{l}3.97 \pm 0.49 \\
P<0.001\end{array}$ & $\begin{array}{l}3.77 \pm 0.38 \\
P<0.001\end{array}$ & $P<0.001$ \\
\hline $\begin{array}{l}\text { Plasma glucose } \\
\text { Mean } \pm \text { SD }(\mathrm{mg} \%)\end{array}$ & $74 \cdot 60 \pm 12 \cdot 41$ & $\begin{array}{l}111.60 \pm 25.92 \\
P<0.001\end{array}$ & $\begin{array}{l}132.24 \pm 35.68 \\
P<0.001\end{array}$ & $P<0.001$ \\
\hline $\begin{array}{l}\text { SGOT } \\
\text { Mean } \pm \text { SD }(\mathrm{Iu} / \mathrm{L})\end{array}$ & $21 \cdot 88 \pm 17 \cdot 14$ & $\begin{array}{l}23.55 \pm 19.23 \\
P>0.3\end{array}$ & $\begin{array}{l}22.22 \pm 18.44 \\
P>0.45\end{array}$ & $P>0.35$ \\
\hline $\begin{array}{l}\text { SGPT } \\
\text { Mean } \pm \text { SD }(\mathrm{Iu} / \mathrm{L})\end{array}$ & $16 \cdot 68 \pm 9 \cdot 62$ & $\underset{P>0.15}{18.62 \pm 11.59}$ & $\begin{array}{l}16.78 \pm 11.02 \\
P>0.45\end{array}$ & $P>0.2$ \\
\hline
\end{tabular}

Table IV Changes in biochemical parameters during hypoglycaemia

\begin{tabular}{ll}
\hline Change in ECG after 2-DG & Number of Patients \\
\hline Ventricular rate change $\pm 20 / \mathrm{min}$ & 4 \\
T-wave changes & 3 \\
S-T segment depression & 4 \\
\hline
\end{tabular}

Table V Changes in electrocardiograph at two hours compared with control reading

\section{Discussion}

Having unequivocally demonstrated the reproducibility of the response to 2-DG in initiating gastric secretion in the patient with intact vagi we may pass on to the side effects encountered in its use.

In considering the actions of 2-DG it is worth recalling that glucose passes through the blood/brain barrier by an active transport system whose capacity is so limited that the rate of glucose transfer is almost maximal at fasting plasma glucose concentrations. Passive diffusion does not occur until the plasma glucose level is greatly elevated (Crone, 1965).

As Agnew and Crone (1967) have reported that glucose and 3-O-methyl glucose have an equal affinity for the blood/brain glucose transport system, and Himsworth and Colin-Jones (1969) have shown that both glucose and 3-O-methyl glucose inhibit the cellular glucopenia usually caused by 2-DG, it is reasonable to assume that glucose and 2-DG compete for this same system.

Once within the cell 2-DG is phosphorylated to 2-DG-6-phosphate (Sols and Crane, 1954), and the resultant hypothalamic glucopenia (Colin-Jones and Himsworth, 1970) excites the dorsal vagal nuclei (Kerr and Preshaw, 1969) with an increase in volume and all components of gastric juice. The extracellular glucose level rises and the hypothalamic glucopenia is gradually reversed as glucose passively diffuses across the blood/brain barrier. The 2-DG is then excreted unchanged in the urine.

Previous reluctance to use 2-DG as a vagal stimulant has stemmed mainly from three published reports: (1) Duke et al (1965) had one patient in whom atrial fibrillation developed following administration of 2-DG, the plasma potassium concentration being $2.7 \mathrm{~m}$ equiv/l at this time. (2) In 1968 Thomas and Duthie in a study comparing 2-DG and insulin in 37 patients found that three patients developed an exaggerated hypoglycaemic reaction with the body temperature falling to $89^{\circ} \mathrm{F}$ with the production of a semicomatose state in one patient. They also quoted unpublished tests in which 2-DG given on the same day as surgery was undertaken might have caused 'mild liver cell damage' in two patients. (3) Himsworth and Colin-Jones (1969) give two theoretical dangers of 2-DG: first, a state of 'profound hypoglycaemia' may be produced in patients with a lower than normal fasting plasma glucose; secondly, reversal of the glucopenia with $50 \%$ glucose solution may produce plasma hyperosmolarity.

Dealing with these reports in order, any fall in serum potassium concentration below normal may induce instability of myocardial conduction. However, as long as the potassium concentration is normal before hypoglycaemia is induced and the test is not continued for more than the two hours of a normal gastric function test, a drop outside the normal range should not occur. The patient quoted by Duke $e t$ al appears to have been hypoglycaemic for at least four hours.

The fall in body temperature, due probably to excessive sweating, may be minimized by conducting the tests in a warm room in which the air is still, and by covering the patient with an air-holding cellular type blanket. No patient among the group who sweated during the test showed a drop in body temperature greater than $0.5^{\circ} \mathrm{C}$ in this report. The patient who became semicomatose with 2-DG and who also exhibited severe hypoglycaemic symptoms with insulin (Thomas and Duthie, 1968) illustrates the point that it is essential to know that the fasting glucose level is within normal limits before giving any glucopenic agent. We knew this value in each patient before proceeding with the test. Armed with 
this result the state of profound hypoglycaemia postulated by Himsworth and Colin-Jones (1969) should never occur.

It is difficult to comment on the evidence for hepatotoxicity quoted by Thomas and Duthie (1968) without fuller knowledge of the cases, but it would seem unwise to anaesthetize a glucopenic patient. However, Franks and Griffen (1968) report giving 2-DG $(50 \mathrm{mg} / \mathrm{kg})$ preoperatively to three patients undergoing vagotomy for duodenal ulcer without adverse effect. Cole (1972) reports an interesting preoperative test for vagal section employing 2-DGinduced glucopenia with the dye neutral red in dogs. He suggests that his results may justify the test being used in man. 2-Deoxy-D-glucose-induced glucopenia during operation need be no more hazardous than glucopenia in the conscious patient provided that the patient is normoglycaemic at induction of anaesthesia and the glucopenia is quickly reversible. Whilst the rate of glucose transport into the cell is limited, as previously mentioned, all hypoglycaemic symptoms following 2-DG can be partially or completely reversed by giving $50 \%$ glucose intravenously (Duke et al, 1965; Johnston, Thomas, Checketts, and Duthie, 1967; Thomas and Duthie, 1968) but certainly not in amounts which would cause the elevation of plasma glucose to the levels quoted by Himsworth and Colin-Jones (1969) in their rat experiments, as their assessment of reversal of hypoglycaemia was the reduction in gastric acid secretion. Plasma hyperosmolarity should not be encountered in the human subject.

The potential use of 2-DG is in providing a safe, effective alternative to the insulin-induced glucopenia in examining both acid secretion and vagal integrity in the duodenal ulcer patient.

Several authors have reported upon the use of 2-DG as a test of complete vagal section following vagotomy (Johnston et al, 1967; Thomas and Duthie, 1968; Stalder, Schultheiss, and Allgower, 1972) and have indicated the superiority of 2-DG over insulin. The production of acid is more rapid and greater in magnitude with 2-DG (Emås and Borg, 1972) and the interpretation of the results unconfused by the 'early' and 'late' responses encountered when using insulin (Stalder et al, 1972).

The short-term reproducibility of the insulin test has been established (Gillespie, Elder, Gillespie, Kay, and Crean, 1970) and we have demonstrated the same with 2-DG in the unoperated patient. There seems no reason to suppose that the postvagotomy patient would show a deviation from this reproducibility although the total acid output levels in these patients would be much reduced.

It should be emphasized that in these tests 2-DG was given to a group of patients whose mean age was only 28 years and who were carefully screened for other disease before proceeding. Constant monitoring of the patient was undertaken and it may be that a greater incidence of side effects would be encountered in performing similar tests with 2-DG in older patients and under less well controlled conditions. This is also true during insulin-induced glucopenia.

We feel that our results, together with those of others published recently (Stalder et al, 1972; Popiela, Szafran, and Szafran, 1972), indicate that when used in carefully controlled gastric function tests 2-DG offers a valuable alternative to insulin in the assessment of the duodenal ulcer patient. The advantage of using the same stimulant both before and after vagotomy in evaluating the degree of reduction in acid secretion is evident, although we do not suggest that 2-DG should completely supersede pentagastrin in the patient with intact vagi. These results provide further evidence that adequately monitored 2-DG glucopenia may provide a useful and relatively safe gastric function test which deserves further study.

\section{References}

Agnew, W. F., and Crone, C. (1967). Permeability of brain capillaries to hexoses and pentoses in the rabbit. Acta physiol. scand., 70, 168-175.

Cole, R. E. (1972). An intraoperative test for the completeness of vagotomy. Amer. J. Surg., 123, 543-544.

Colin-Jones, D. G., and Himsworth, R. L. (1970). The location of the chemoreceptor controlling gastric acid secretion during hypoglycaemia. J. Physiol. (Lond.), 206, 397-409.

Crone, C. (1965). Facilitated transfer of glucose from blood into brain tissue. J. Physiol. (Lond.), 181, 103-113.

Duke, W. W., Hirschowitz, B. I., and Sachs, G. (1965). Vagal stimulation of gastric secretion in man by 2-deoxy-D-glucose. Lancet 2, 871-876.

Eisenberg, M. M., Emàs, G. S., and Grossman, M. I. (1966). Comparison of the effect of 2-deoxy-D-glucose and insulin on gastric acid secretion in dogs. Surgery, 60, 111-117.

Emås, S., and Borg, I. (1972). Stimulation of gastric acid secretion by insulin and 2-deoxy-D-glucose in duodenal ulcer patients. Digestion, 7, 44-53.

Findlay, J. M., Prescott, R. J., and Sircus, W. (1972). A comparative evaluation of water recovery test and fluoroscopic screening in positioning a nasogastric tube during gastric secretory studies. Brit. med. J., 4, 458-461.

Franks, C. D., and Griffen, W. O., Jr. (1968). An intraoperative test for complete vagal section. Surg. Forum, 19, 318-320.

Gillespie, G., Elder, J. B., Gillespie, I. E., Kay, A. W., and Crean, G. P. (1970). The short term reproducibility of the insulin test in peptic ulcer patients. Gastroenterology, 59, 180-187.

Hassan, M. A., and Hobsley, M. (1970). Positioning of subject and of nasogastric tube during a gastric secretion study. Brit. med. J. 1, 458-460.

Himsworth, R. L., and Colin-Jones, D. G. (1969). Factors which determine the gastric secretory response to 2-deoxy-D-glucose. Gut, 10, 1015-1019.

Hirschowitz, B. I., and Sachs, G. (1965). Vagal gastric secretory stimulation by 2-deoxy-D-glucose. Amer. J. Physiol., 209, 452-460.

Johnston, D., Thomas, D. G., Checketts, R. G., and Duthie, H. L. (1967). An assessment of post-operative testing for completeness of vagotomy. Brit. J. Surg., 54, 831-833.

Kerr, F. W. L., and Preshaw, R. M. (1969). Secretomotor function of 
the dorsal motor nucleus of the vagus. J. Physiol. (Lond.). 205, $405-415$.

Popiela, T., Szafran, H., and Szafran, Z. (1972). Evaluation of the completeness of vagotomy in patients with duodenal ulcer basing on insulin test and test using 2-deoxy-D-glucose. (Polish.) Przegl. Lek., 29, 748-755.

Sols, A., and Crane, R. K. (1954). Substrate specificity of brain hexokinase. J. biol. Chem., 210, 581-587.

Stalder, G. A., Schultheiss, H. R., and Allgower, M. (1972). Use of 2-deoxy-D-glucose for testing completeness of vagotomy in man. Gastroenterology, 63, 552-556.

Thomas, D. G., and Duthie, H. L. (1968). Use of 2-deoxy-D-glucose to test for the completeness of surgical vagotomy. Gut, 9, 125-128. 